\title{
高速掃引型波束分光計測による分子振動ダイナミクスの量子波束制御
}

\author{
三沢和彦，堀越建吾 \\ 東京農工大学 共生科学技術研究院
}

\section{Vibrational Wave-Packet Engineering by Rapid-Scanning Wave-Packet Spectroscopy}

\author{
Kazuhiko MISAWA and Kengo HORIKOSHI \\ Tokyo University of Agriculture and Technology
}

(Received November 1, 2009)

\begin{abstract}
Open-loop wave-packet engineering was demonstrated by full capture of the phase-controlled vibrational motions by means of our newly developed wave-packet spectrometer. Optimal parameters of tailored femtosecond pulses from a pulse shaper were obtained for selective excitation of either twisting or bending motion in two different cyanine dye molecules. Mode-selective wave-packet generation by chirped pulse sequences was found to be commonly effective for both DTTCI and IR-140. These results suggest a promising step toward triggering chemical reactions to a desired target by guiding the wavepacket motions associated with conformational changes in the substances.
\end{abstract}

Key Words: Vibrational wave packet, Coherent control, Pulse shaping, Rapid-scanning wave-packet spectroscopy, Chirped pulse sequence

1.はじめに :

これまでのコヒーレント制御実験における問題点

1.1 最適制御実験による反応制御メカニズム解明の 限界

光解離あるいは光異性化といった多くの光化学反応過 程は, フェムト秒の時間領域で観測される ${ }^{1,2)}$. 近年, モード同期超短パルスレーザーによって, これらの化学 反応を観察するだけでなく, 制御することも可能になっ た. 分子振動の周期よりも短いフェムト秒パルスを用い れば, 分子の核運動をコヒーレントに励起することがで きる. 光励起された分子の核運動によって誘起される反 応の生成収率は, 光励起直後の系の初期状態に依存し, その初期状態は, 励起パルスの時間波形に応じて変化さ せることができる。このように，化学反応に関連した超 高速ダイナミクスを励起パルス波形によって制御しよう という研究は, 最近10年間で急速に進歩してきた ${ }^{3)}$.

この分野での最大の課題は, 反応過程を望ましい生成 物状態に導く最適パルス波形の探索方法を確立すること である，最も成功した手法として，学習アルゴリズム ${ }^{4)}$ によってパルス波形を最適化する「フィードバック制御」 がある。このフィードバック制御では，主に最終生成物 のみを指標として, 反応過程を導くためのパルス波形が 自動的に最適化される。このアプローチは，色素分子の ポピュレーション移動 ${ }^{5)}$, 有機金属の光解離(), 生物系 におけるエネルギー移動7), ドレスト状態の選択的な励 起 $^{8)}$, さらには半導体における光学的非線形性 ${ }^{9)}$ といっ た広範囲のコヒーレント制御実験において効果的である

\section{ことを実証されてきた}

学習アルゴリズムは強力な手法ではあるが10), フィー ドバックの結果として生じるパルス波形だけでは，どの ようなメカニズムで最適パルス波形が決まるかを論じる ことは困難である。メカニズムを決定するには反応の初 期状態から最終状態に至るまでの過渡的過程を直接観察 することが必要である. ダイナミクスの直接観測の結果 として，最適パルス波形を決定することが望ましい．

フェムト秒パルスを整形することによる反応制御は, ポテンシャルエネルギー面の上に拀いて波束運動を反応 座標の方向へ誘導することによって実現する。したがっ て，望ましい目標に波束運動を誘導することのできる励 起パルスの最適形を調べることが直接の目的となる。実 際には，学習アルゴリズムを用いた適応制御実験の最適 パルス波形が，結果としてパルス列となっていることが 多い7,8,11)。そそような場合は，パルス列に同期した振動 モードを選択的に励起したことが, 反応制御のメカニズ ムである，と推測されている。

このような状況では，同期した振動モードを選択的に 励起するというメカニズムを前提に，初めから，パルス 列といった限られた数のパラメータで指定できるパルス 波形に探索範囲を限定することが，物理的なメカニズム を絞り込むことにとって有意義である ${ }^{11)}$. 制御メカニズ ムを解明するためには, 少数のパラメー夕を変化させな がら，制御された波束運動を実時間で観察することを通 して, 最適パラメータを探索する戦略が, 学習ループ実 験より有利と考えられる。 
1.2 従来のポンプープローブ実験における測定の長 時間化

波束運動の描像は, 周波数分解かつ時間分解した透過 率変化 (時間分解透過率スペクトル) から抽出することが できる ${ }^{12)}$. この透過率変化の測定には, 励起光に依存し ない大きなバックグラウンド信号に対して，励起光に よって誘起されたプローブ強度の小さな変化を検出する 必要があるため, 従来の実験では, 光学式チョッパーと ロックイン増幅器の組み合わせが使われてきた。ロック イン検出では, 信号雑音比を向上させるために, 単一の データ点でロックイン時定数の積分時間が必要となる. 時間分解測定では, 各々の遅延時間においてこの積分時 間が必要となり，必然的にデータセット全体の収集時間 が増えてしまう。測定が長時間にわたる場合は, 時間遅 延を掃引している間にレーザーのゆらぎやドリフトによ り，データ全体の信頼性が低下してしまう。 それゆえ， パルス波形パラメータを広範囲にわたって探索する実験 を行うためには，1つのパラメータ条件における測定時 間ができるだけ短時間であることが望まれる，

そこで, 我々は, 高速遅延掃引装置および, 分光器, フォトダイオードアレイ, 電気ハイパスフィルタのセッ トと組み合わせることによって，信号雑音比にきわめて 優れた波束分光計を開発した ${ }^{13)}$ 。この波束分光計は，ひ とつの励起パルス条件における時間分解透過率変化スペ クトルを，わずか1分で取得できる。この1分の測定時間 では， $10^{-5}$ の信号検出限界が達成でき，位相制御された 波束運動についての詳細な情報を読み取るのに十分な信 号雑音比が得られる.

本論文では，シアニン色素分子を試料として，この高 速掃引型波束分光計を用いた分子振動核波束のコヒーレ ント制御を実証する。チャープパルス列によって光励起 した波束のダイナミクスを観測し，パルス列におけるパ ルスチャープとサブパルス間隔について最適值を探索し た。 その結果, シアニン分子のねじれ運動あるいは曲げ 運動と関連した振動モードの波束を選択的に励起するこ とに成功した。

\section{2. 高速掃引型波束分光計を用いた 波束ダイナミクスの測定}

\section{1 高速掃引型波束分光計}

開発した分光計は, パルス整形器と高速掃引型の遅延 時間装置の両方がポンプパルスの光路に挿入されたポン プープローブ装置である. チタンサファイヤレーザー発 振器 (Femto Source Pro, Femto Lasers) からは, パルス幅 $14 \mathrm{fs}$, パルスエネルギー $5 \mathrm{~nJ}$, 繰返周波数 $78 \mathrm{MHz}$ のパル ス列が出力される。このパルスをポンプパルスとプロー

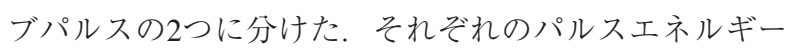

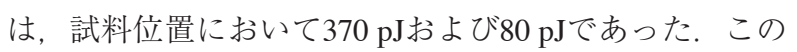
励起パルスのパルス面積は, $\pi / 8$ 程度に相当し, 弱励起 の条件であるとみなしてよい. プローブパルスの時間幅 はすべての実験で14fsである。試料を透過したプローブ パルスは分光器でスペクトル分解され, 各スペクトル成
分の強度を35チャンネルのフォトダイオードアレイで測 定した。同時に測定できる波長範囲は140 nmにわたり， 波長分解能は $4 \mathrm{~nm}$ 程度であった。この波長分解能は, プローブ光子エネルギーに換算すると, $0.01 \mathrm{eV}$ 分解 能にあたる。

遅延時間装置の掃引周波数は, 最大 $20 \mathrm{~Hz}$ であるが, 今回の実験では, $\mathrm{A} / \mathrm{D}$ 変換後のデータ取り达みレートの 制限から， $6.1 \mathrm{~Hz}$ とた。 ポンプパルスによって誘起さ れたプローブ光強度の変化は，遅延時間の掃引周波数に 同期しているため，フォトダイオードからの出力信号も 掃引周波数の整数倍の交流成分から成っている。この交 流成分は，電気的ハイパスフィルターを用いて，ポンプ パルスに依存しないバックグラウンドから分離できる.

各々の波長におけるプローブ強度は，32チャンネルの $\mathrm{AD}$ 変換器 (Compact DAQ, National Instruments)により遅 延時間の関数として記録した。

\section{2 フェムト秒位相制御パルス光源}

パルス整形器は2対の回折格子と凹面鏡からなるゼロ 分散光学系である ${ }^{15)}$. このゼロ分散光学系には, 一列に 128個の画素を含む液晶空間光位相変調器 (SLM-256,

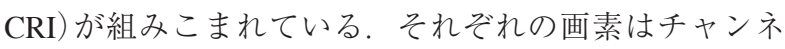
ルごとの電圧信号によって, 屈折率を変化させることが でき, 結果として各画素を通過したスペクトル成分に位 相シフトを与える。この装置を使って, 我々はチャープ パルス，パルス列およびチャープパルス列を生成した。 チャープパルスは, 周波数に対して2次関数となる位相 シフトをSLMに加えることで発生させた。 ポンプパル スに与えた 2 次分散の範囲は, + 600 から- $600 \mathrm{fs}^{2}$ までと した。また，パルス列は，正弦関数型位相変調によって 発生させた。サブパルス間隔は, 正弦関数の周期を変え ることによって調整し，パルス列におけるサブパルスの 数とサブパルス間の振幅比は, 正弦関数型変調の深さに よって制御できる. 正弦関数型変調の深さを1.9ラジア ンに設定した結果，入射したフーリエ変換限界パルス は，ほとんど等しい振幅の3つのパルスに分けられた。 さらに，すべてのサブパルスが等しくチャープしたよう なチャープパルス列は, 2次関数と正弦関数の位相シフ トをSLMで重ね合わせて生成した。本実験においては, 波束制御のためのパラメータとして，2次分散とサブパ ルス間隔の2つに制限して，最適条件を探索した。

\section{3 試 料}

試料分子は，2種類のシアニン色素，3,3'-Diethylthiatricarbocyanine Iodide(DTTCI) とIR-140である。これらの分 子には，電子励起に結合した $2 つ の$ 主な振動モードがあ り，分子軌道計算からは，これらのモードが分子のねじ れ運動と曲げ運動に対応することが確かめられてい る ${ }^{16)}$. この2つのモードに関連する振動量子波束の運動 を，最適に整形されたパルスによってどちらか一方の配 位座標に沿って励振されうるかどうか調べた。試料は, 濃度50 $\mu \mathrm{M}$ のエタノール溶液である。励起の蓄積を避け るために, マグネットギヤポンプ(RegloZ, Isomatec)を 
用いてセル厚 $0.5 \mathrm{~mm}$ の石英フローセル内を循環させ た. 散乱によりプローブ光の強度変動の原因となる試料 溶液中のゴミを除去するために，七ルに通す前にメンブ レンフィルター(Millex-AP50, ミリポア)によってろ過 した

\section{3. チャープパルス列による} 分子振動波束のモード選択励起

\subsection{DTTCI分子}

ポンプパルスの2次分散を+600から-600 fs ${ }^{2}$ 範囲に おいて $50 \mathrm{fs}^{2}$ 間隔で変化させ，それぞれの2次分散の值ご とに周波数および時間分解された非線形透過率変化を測 定した. Fig. 1 (a) と1（b）は，2次分散の值が-200およ び+200 fs ${ }^{2}$ でチャープしたパルス励起の場合について, 試料をDTTCIとして得られた時間分解スペクトログラム を示す。透過率は遅延時間全域にわたって誘導放出によ り増加しているが, 励起状態の寿命を反映した遅い減衰 成分に, 分子振動波束ダイナミクスを起源とする振動構 造が重畳している。振動構造は, 長寿命の減衰成分を差 し引くことによって抽出した. Fig. 1のスペクトログラ ムは, 抽出した振動成分の増加分を白色, 減少分を黑色 の濃淡で表した3次元プロットである。縦軸が周波数分 解したプローブ光子エネルギー，横軸がポンプパルスと プローブパルスの遅延時間になっている.

光反応性の分子系においては, 光誘起された後の励起 状態における時間的発展が極めて重要である ${ }^{17)}$. 電子基 底状態における核配置の安定状態から, 電子励起によっ て核の安定配置が変化し, 分子振動が誘起される。

Fig. 1 (a) (b)の時間分解スペクトルグラムからは, 電子 励起状態のポテンシャルエネルギー面上で波束が周回運 動していることが読み取れる。Fig. 1 (a) (b)で明るい部

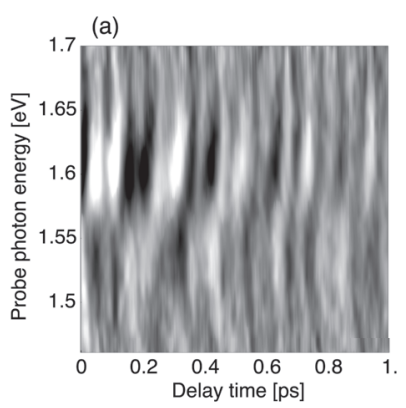

(b)
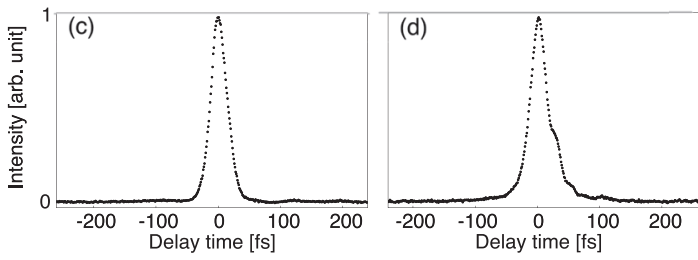

Fig. 1 Frequency- and time-resolved nonlinear susceptivility spectrograms representing vibrational wavepacket dynamics in DTTCI for (a) negatively $\left(-200 \mathrm{fs}^{2}\right)$ and (b) positively $\left(+200 \mathrm{fs}^{2}\right)$ chirped excitations. Sum-frequency intensity cross-correlation traces of the excitation pulses are also depicted in (c) and (d).
分が波束の局在している位置に対応し，この明るい部分 は1.57 eVを中心に， $1.52 \mathrm{eVから} 1.62 \mathrm{eV}$ の間を周期的に 往復している様子がわかる。DTTCIの定常吸収と定常螢 光のピークはそれぞれ実測值で $1.619 \mathrm{eV}$ と $1.565 \mathrm{eV}$ で あった。定常吸収におけるフランクーコンドン遷移エネ ルギーは周回運動の内側の転回点と一致し，さらに，螢 光ピークの光子エネルギーは周回運動の中点に一致して いる. 周回運動の内側の転回点が定常吸収ピークに一致 し, 周回運動の中点が定常螢光ピークに一致するという 事実は，Fig. 2で示すように，その波束が励起状態ポテ ンシャルエネルギー面の上にあることの証明となる.

Fig. 2は1次元ポテンシャルでのモデル図であるが, 2次 元ポテンシャルでも同様の議論が成り立つ ${ }^{16)}$.

2次分散値- $200 \mathrm{fs}^{2}$ の負チャープパルスで励起した場

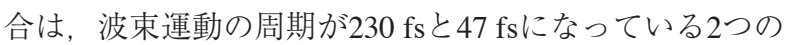
振動成分が観測された。これらの振動周期は，それぞ れ，4.5 THzと $15 \mathrm{THz}$ モド振動数に対応する。 $4.5 \mathrm{THz}$ および15 THzのモードは，それぞれDTTCI分子のねじれ 運動と曲げ運動に関係がある。他方で，2次分散值 + $200 \mathrm{fs}^{2}$ の正チャープパルスで励起した場合は $15 \mathrm{THz} の$ 振動がほぼ完全に消滅することがわかる．励起パルスの 和周波強度交差相関波形の半值幅は, Fig. 1 (c) と 1 (d) で示すように負チャープと正チャープパルスの場合で, それぞれ30と31 fsであった。 パルス幅がほぼ等しいにも かかわらず，負チャープと正チャープのパルスで，非常 に異なる信号を与えている。

Fig. 3 (a) と3 (b) は, 波束運動による振動スペクトル の2次分散依存性を示す。各々の図は，それぞれの分光 チャンネルにおける時間分解波形をフーリエ変換した 後, 分光チャンネルごとのフーリエスペクトルについて 全32チャンネルにわたって総和をとり，50 fs ${ }^{2}$ おきに25 本のフーリエスペクトルを並べて図示したものである. 分光チャンネルの総和をとらずに，振動構造が最も明瞭 に観測される定常吸収ピークエネルギーに相当するチャ

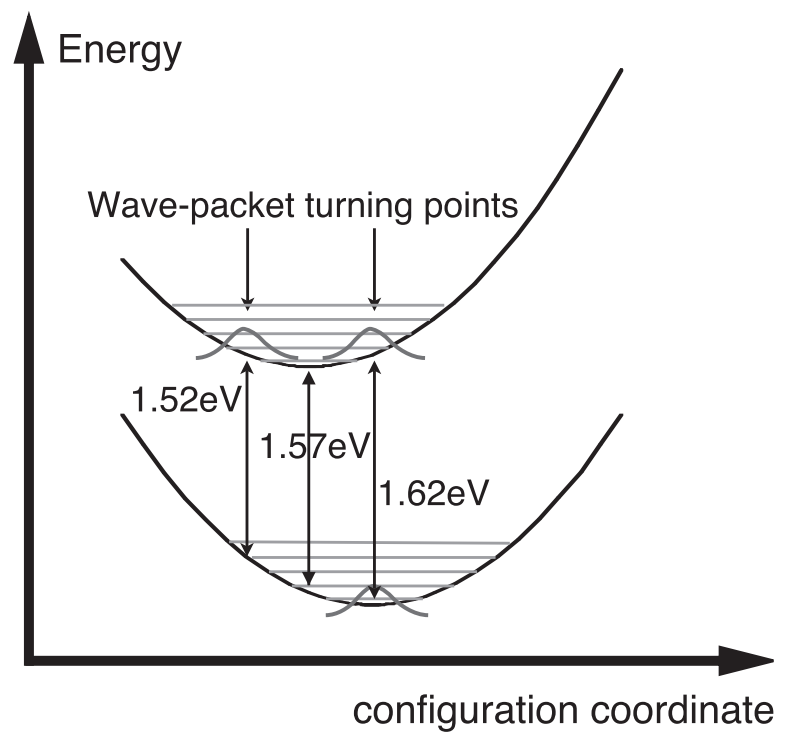

Fig. 2 Potential energy surfaces of shifted harmonic oscillators. 


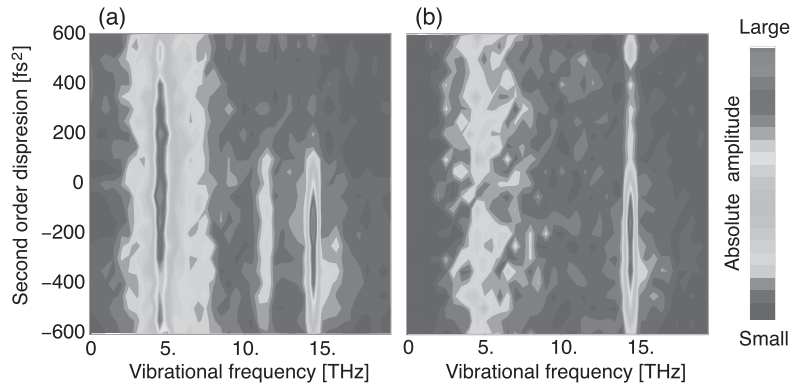

Fig. 3 Second-order-dispersion dependence of the vibrational spectra of the wave-packet motion in DTTCI for (a) a single chirped pulse and (b) triplet chirped-pulse sequence.

ンネルだけをプロットしても等価な眓が描けるが, 結果 は大きく変わらない. しかしながら, Fig. 3の結果は, プローブパルスを分光せずにパルス全体の透過率を計測 し，フーリエスペクトルに換算したものとは等価でな い. なぜなら, Fig. 1でわかるように, プローブパルス のスペクトル内で同じ振動周波数であっても, 波束運動 の両側の転回点では振動構造の位相が逆転しており, ス ペクトル全体にわたって積分した透過率変化では逆振動 がキャンセルされてしまうからである，本方法は，時間 分解透過率変化スペクトルを測定することによって, 分 子振動に伴う透過率変化の振幅と位相とを独立に求める ことができる点で優れている.

Fig. 3 (a)で示す2次分散依存性は, $15 \mathrm{THz}$ の振動モー ドが2次分散の值に敏感であることを表している。正 チャープパルスによる励起では, $15 \mathrm{THz}$ の振動が抑え られていることが図よりわかる ${ }^{18)} .4 .5 \mathrm{THz}$ 運動が - 400から+400 fs ${ }^{2}$ までほとんど全部の範囲で観測される

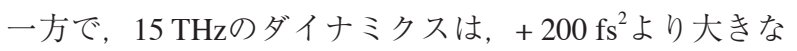
2次分散で見られない. したがって，2次分散值が+200 と+400 $\mathrm{fs}^{2}$ の間であれば, $4.5 \mathrm{THz}$ のダイナミクスを選択 的に生成できることになる。ここでの重要な結果は, チャープによるダイナミクスの違いは, 単にチャープに よってパルス幅が広がったためではなく, スペクトル位 相の違いだけによるということである.

基底状態と励起状態とで振動周波数が等しく, 極小点 が変位しただけの調和振動子モデルでは，フランク・コ ンドン遷移で励起される波束の初期状態は, チャープの 向きに依存しない。したがって，この実験において， チャープの大きさが等しい条件でもチャープの向きに よって励起された波束のダイナミクスが異なるのは, ポ テンシャルエネルギー面に非調和性が現れる場合か, あ るいは非調和性は小さくても基底状態と励起状態とで振 動周波数が異なる場合が理由として考えられる。たた し，すでに筆者らが報告したように ${ }^{16) ， D T T C I て ゙ は ホ ゚ テ ~}$ ンシャルの変位が小さく, 非調和性の影響は無視できる 程度であることがわかっている. 現在, 基底状態と励起 状態とで振動周波数が異なる条件で, 実験結果の解釈を 試みているところである。

$15 \mathrm{THz}$ モードの選択励起は, 単にチャープしたポン プパルスだけでは可能でなく, 正弦型位相変調によって
発生されるパルス列を用いることによって実現した。こ のとき, パルス列のパルス間隔は，分子振動周期に同期 させる目的で, $15 \mathrm{THz}$ の逆数に相当する $67 \mathrm{fs} に$ 合わせ た．以前の適応制御実験では，最適パルス波形を探索す ると，結果としてパルス列になったものが多い。今回の 実験では，パルス列で同期的に励起された $15 \mathrm{THz}$ の振 動成分の振幅は, 正弦型位相変調にさらに負の2次分散 を加えることによって増強された。 そこで，単一の チャープパルスと同様に，チャープした3連パルスの2次 分散パラメータの関数として, 振動スペクトルを測定し た。このとき，サブパルスの間隔は67fsで固定してあ る。測定された振動スペクトルの2次分散依存性を Fig. 3 (b) に示す. 2次分散值のすべての範囲で, $4.5 \mathrm{THz}$ のモードが弱くなっているのは，パルス列の破壊的干渉 の効果である. $15 \mathrm{THz}$ モドのフーリエ振幅は, 2次分 散- $150 \mathrm{fs}^{2}$ で最大になり, 単一のチャープパルスの場合 と類似している。 また, 正チャープの領域では, 単一 チャープパルス励起と同様に消滅している. Fig. 4 (a) と4（b)は， - $150 \mathrm{fs}^{2}$ の負チャープの3連パルスの場合に おける時間分解スペクトログラムと, 励起パルスの和周 波強度相互相関波形を表す。 - $150 \mathrm{fs}^{2}$ のチャープがか かったパルスでも，ひとつのサブパルスの幅は30 fs程度 であり， $67 \mathrm{fs} の$ 振動周期に対しても広がりすぎてはいな い.したがって，2次分散值-150 fs ${ }^{2}$ は，ポテンシャルエ

(a)
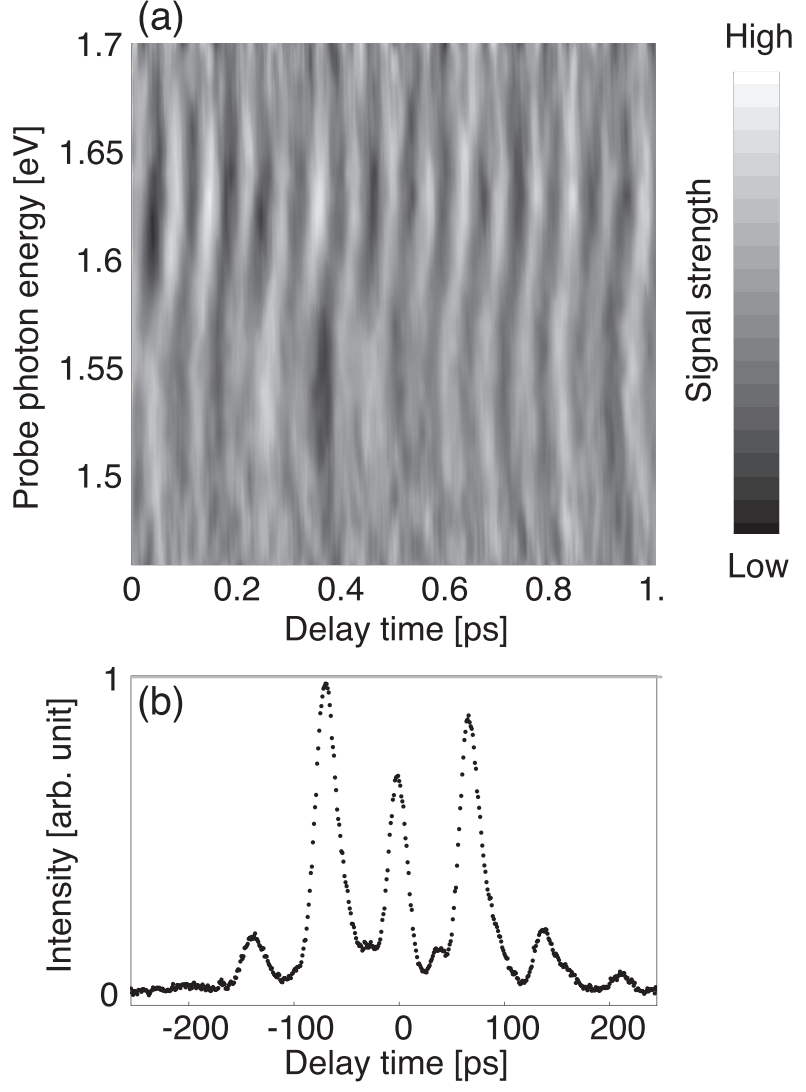

Fig. 4 (a) Frequency- and time-resolved nonlinear susceptivility spectrograms for DTTCI in case of negatively chirped triplet pulses at $-150 \mathrm{fs}^{2}$, and (b) sum-frequency intensity cross-correlation trace of the excitation pulse sequence. 


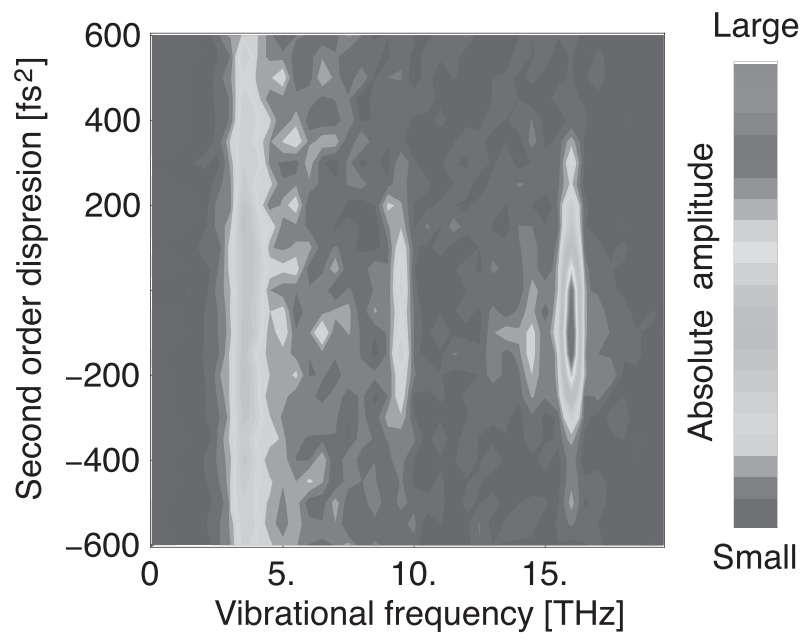

Fig. 5 Second-order-dispersion dependence of the vibrational spectra of the wave-packet motion in IR-140 for a single chirped pulse.

ネルギー面の形状に対して最適な条件に相当すると予測 されるが, 詳しい理由は考察中である。このように，高 速掃引型波束分光計を用いることにより，位相制御され た波束運動を完全に捕捉しながら，波束運動を最適化で きたといえる。

\subsection{IR-140分子}

チャープしたパルス列のモード選択性が，シアニン系 有機分子において一般的な現象であるかどうかを確かめ るために，もう1種のシアニン色素 $\left(\right.$ IR- $\left.140^{20)}\right)$ を試料と して, 波束の位相制御を試みた。定常吸収および蛍光 ピークは，それぞれ， $1.534 \mathrm{eV}$ と $1.471 \mathrm{eVであり,} \mathrm{DTTCI}$ と比較して低エネルギーシフトしている。 IR-140分子は DTTCI同様にカルボシアニンであるが, 分子の共役主鎖 の中央に五員環が架橋されている。これにより，ねじれ 運動と曲げ運動は制限されると予測されるため, IR-140 の波束生成および制御の結果をDTTCIと比較するのは有 益である.

チャープパルス列を用いたモード選択波束生成は, IR-140分子に対しても効果がみられた. IR-140分子の波 束運動の応答は, DTTCIの場合ときわめて類似してお り, 負チャープしたパルスは3.8と $17 \mathrm{THz}$ のつの振動 モードを励起する。 Fig. 5には, IR-140に対する振動ス ペクトルのチャープ依存性を示す。17 THzのモード振 幅は, DTTCI分子同様に, 2次分散の- $150 \mathrm{fs}^{2}$ 付近で増強

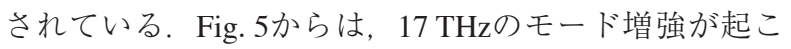
る2次分散は比較的狭い範囲に限定されていることもわ かる，他方，3.8 THzの運動は2次分散值にあまり依存せ ず，一様に観測された。このように，DTTCIだけでなく IR-140分子についても $3.8 \mathrm{THz}$ モードと関連した波束 を選択的に発生させることができた。DTTCIと同様に, 3連チャープパルスを用いた場合には, サブパルス間隔 が17 THzに同期したときに，17 THzモードの選択励起
が実現した。このように，波形整形パルスによるモード 選択的波束励起は，シアニン色素分子のねじれ運動およ び曲げ運動に関して共通した現象であると考えられる。

\section{4. 結 論}

我々は, フェムト秒位相制御光源で波形整形したフェ ムト秒パルスを用いて, 振動量子波束の制御を実証し た。制御パラメータの探索においては，1分程度の短時 間で波束ダイナミクスについての詳細な情報を捕捉でき る高速掃引型波束分光計を新しく開発し, この高速掃引 型波束分光計によって, 波束ダイナミクスの直接観測と 制御とを実現した。2つの異なるシアニン色素分子 DTTCIとIR-140を対象に，正チャープした単一パルスあ るいは負チャープした3連パルスを用いることで，それ ぞれ，ねじれ運動あるいは曲げ運動の選択励起に成功し た。この結果により，物質の構造変化と関連した波束運 動を制御することによって，化学反応を望ましい反応過 程へと誘導する手法の可能性が示されたといえよう.

\section{謝 辞}

本実験結果の理論的解勫に関して，東芝研究開発セン ターの石田邦夫氏に有益な助言をいただきました。

\section{参考文献}

1) A. H. Zewail: J. Phys. Chem. A 104(2000) 5660.

2) F. C. D. Schryver, S. D. Feyter, G. Schweitzer, eds.: Femtochemistry: With the Nobel Lecture of A. Zewail (Wiley-VCH, 2001).

3) S. A. Rice and M. Zhao: Optical Control of Molecular Dynamics (Wiley, 2000).

4) R. S. Judson and H. Rabitz: Phys. Rev. Lett. 68 (1992) 1500.

5) C. J. Bardeen, et al.: Chem. Phys. Lett. 280 (1997) 151.

6) A. Assion, et al.: Science 282 (1998) 919.

7) J. L. Herek, W. Wohlleben, R. J. Cogdell, D. Zeidler, and M. Motzkus: Nature 417 (2002) 533.

8) M. Wollenhaupt, D. Liese, A. Prakelt, C. Sarpe-Tudoran, and T. Baumert: Chem. Phys. Lett. 419 (2006) 184.

9) J. Kunde, et al.: Appl. Phys. Lett. 77 (2000) 924.

10) H. Rabitz, M. Hsieh, and C. Rosenthal: J. Chem. Phys. 124 (2006) 204107.

11) T. Hornung, R. Meier, and M. Motzkus: Chem. Phys. Lett. 326 (2000) 445.

12) W. T. Pollard, S.-Y. Lee, and R. A. Mathies: J. Chem. Phys. 92 (1990) 4012.

13) K. Horikoshi, K. Misawa, R. Lang, and K. Ishida: Opt. Commun. 259 (2006) 723.

14) K. Misawa and T. Kobayashi: J. Chem. Phys. 113 (2000) 7546.

15) A. M. Weiner, D. E. Leaird, J. S. Patel, and J. R. Wullert: Opt. Lett. 15 (1990) 326.

16) K. Ishida, F. Aiga, and K. Misawa: J. Chem. Phys. 127 (2007) 194304.

17) J. Hauer, T. Buckup, and M. Motzkus: Chem. Phys. 350 (2008) 220.

18) K. Horikoshi, K. Misawa, and R. Lang: J. Chem. Phys. 127 (2007) 054104.

19) G. Vogt, P. Nuernberger, R. Selle, F. Dimler, T. Brixner, and G. Gerber: Phys. Rev. A 74 (2006) 033413. 